\title{
Review Article \\ Obesity and Inflammation: Epidemiology, Risk Factors, and Markers of Inflammation
}

\author{
Heriberto Rodríguez-Hernández, ${ }^{1,2}$ Luis E. Simental-Mendía, ${ }^{1}$ \\ Gabriela Rodríguez-Ramírez, ${ }^{1}$ and Miguel A. Reyes-Romero ${ }^{2}$ \\ ${ }^{1}$ Biomedical Research Unit of the Mexican Social Security Institute at Durango, Predio Canoas 100, Los Angeles, \\ 34067 Durango, DGO, Mexico \\ ${ }^{2}$ Faculty of Medicine and Nutrition, Juárez University of Durango State, Av. Universidad and Fanny Anitúa s/n, \\ Zona Centro, 34000 Durango, DGO, Mexico
}

Correspondence should be addressed to Luis E. Simental-Mendía; luis_simental81@hotmail.com

Received 14 January 2013; Accepted 27 March 2013

Academic Editor: Abdelfattah El Ouaamari

Copyright (c) 2013 Heriberto Rodríguez-Hernández et al. This is an open access article distributed under the Creative Commons Attribution License, which permits unrestricted use, distribution, and reproduction in any medium, provided the original work is properly cited.

\begin{abstract}
Obesity is a public health problem that has reached epidemic proportions with an increasing worldwide prevalence. The global emergence of obesity increases the risk of developing chronic metabolic disorders. Thus, it is an economic issue that increased the costs of the comorbidities associated. Moreover, in recent years, it has been demonstrated that obesity is associated with chronic systemic inflammation, this status is conditioned by the innate immune system activation in adipose tissue that promotes an increase in the production and release of pro-inflammatory cytokines that contribute to the triggering of the systemic acute-phase response which is characterized by elevation of acute-phase protein levels. On this regard, low-grade chronic inflammation is a characteristic of various chronic diseases such as metabolic syndrome, cardiovascular disease, diabetes, hypertension, non-alcoholic fatty liver disease, and some cancers, among others, which are also characterized by obesity condition. Thus, a growing body of evidence supports the important role that is played by the inflammatory response in obesity condition and the pathogenesis of chronic diseases related.
\end{abstract}

\section{Epidemiology and Obesity}

Obesity is actually an epidemic problem in the world; it has become truly a global problem affecting countries rich and poor. An estimated 500 million adults worldwide are obese and 1.5 billion are overweight or obese [1]. Particularly the prevalence of obesity or combined overweight and obesity has increased in Brazil, Canada, Mexico, and United States [2]. Much of the information about obesity among adults rest in the use of body mass index (BMI) to define obesity, which will be defined as a BMI $30 \mathrm{~kg} / \mathrm{m}^{2}$ or greater unless otherwise stated [3]. An examination of national data through 1991 confirmed that significant increases in the United States population had takes place both in adults and children and adolescents [4, 5]. The most recent data from 2005-2006 show that $33.3 \%$ of men and $35.3 \%$ of women were obese [6]. In Canada, the prevalence of obesity based on measured height and weight has almost doubled in the last two decades and now affects $23 \%$ of the adult population [7].

Obesity is a consequence of many risk factors, as increased energy consumption and reduced physical exercise. Many studies also implicate chronic low grade inflammation in the interplay between obesity and metabolic complications, as many chronic degenerative disorders, including atherosclerosis, and are also commonly associated with hypertension, which itself has also been linked recently to inflammation $[8,9]$. Obesity and inflammation have been associated with type 2 diabetes, cardiovascular disease, hypertension, stroke, and gallbladder disease, some forms of cancer, osteoarthritis, and psychosocial problems [10]. In obesity subjects, this problem is commonly associated with other metabolic disorders as hyperglycemia and hypertriglyceridemia, which are well-known risk factors for developing chronic liver disease, as nonalcoholic fatty liver disease 
(NAFLD) [11, 12]. The prevalence of NAFLD reaches $14 \%$ to $21 \%$, but is it as high as $90 \%-95 \%$ in obese persons and up to $70 \%$ in diabetic patients [13]. Liver inflammation can be induced by the metabolically active intraabdominal fat, and that the high BMI and large waist circumference are significantly associated with the elevation of aspartate aminotransferase (AST) and alanine aminotransferase (ALT) levels $[14,15]$. Patients with obesity can have elevation of AST and ALT levels, and the reduction of body weight can be achieved with combining diet and physical activity strategies, and reduced levels of aminotransferase [16]. NAFLD and cardiovascular disease have common metabolic risk factors and have $3.7 \%$ on mortality; individuals with NAFLD were older, predominantly males, and more likely to be Hispanic. They also had a higher prevalence of all components of metabolic syndrome and cardiovascular disease; however, patients with NAFLD disease did not increase cardiovascular mortality in over 14 years [17].

For example, within the context of chronic $\mathrm{HCV}$ and $\mathrm{HBV}$ infection, the presence of cirrhosis is the most important risk factor in the development of hepatocellular carcinoma [18]. There are some nonmodifiable risk factors including older age, male gender, and family history, and several modifiable risk factors in hepatocelular carcinoma, of which the most important are alcohol and tobacco [19]. However, identifying additional modifiable risk factors, including diet, is important, including coffee and tea, fructose, iron, red and with meats, types of fat, selenium, and vitamins D and E [20].

Diet and life style play a crucial role in the development of some cancers. Actually in Mexico and others countries, more than one-third of cancer deaths can be avoided through dietary modification. Different mechanisms, including antioxidant, anti-inflammatory, and antiestrogenic processes, have been proposed to explain the protective nature of certain dietary components [21].

\section{Obesity and Chronic Inflammation}

Inflammation is a physiological response necessary to restore homeostasis altered by diverse stimuli; however, inflammation state chronically established or an excessive response can involve deleterious effects. In overweight and obesity, there exists low-grade chronic inflammation; recent studies have unveiled some of the intracellular pathways of inflammation associated with these conditions; studies in mice and humans evidence that consumption of nutrients may acutely evoke inflammatory responses; so, it is thought that the starting signal of inflammation is overfeeding and the pathway origins in tissues involved in metabolism, that is, adipose tissue, liver, and muscle, which in response of this stimulus triggers the inflammatory response $[22,23]$. Compared with lean control, in obese men and women, tissue and liver tissues display an increased activation of kinases such as c-jun $\mathrm{N}$ terminal kinase and the inhibitor of $\mathrm{k}$ kinase, which are able to induce the expression of inflammatory cytokines $[24,25]$. These kinases regulate downstream transcriptional programs through the transcription factors activator protein1 , nuclear factor $\kappa \mathrm{B}$, and interferon regulatory factor, inducing upregulation of inflammatory mediator gene expression.
The increase in cytokines exacerbates receptor activation by establishing a positive feedback loop of inflammation and the inhibitory signaling of metabolic pathways [26].

Likewise, inflammasome and the Toll-like receptors (TLRs) of the innate immune system are activated as well $[27,28]$. Now, strong evidences indicate a prominent role of the inflammasome signaling in the development of a chronic proinflammatory state that impairs insulin sensitivity [24].

\section{The Inflammasome}

Inflammasome is a macromolecular innate immune cell sensor that initiates the inflammatory response. Recognition of diverse noxious signals by the inflammasome results in activation of caspase-1, which subsequently induces secretion of potent proinflammatory cytokines, particularly interleukin$1 \beta$ (IL-1 $\beta$ ). In this way, inflammasome-mediated processes are important in regulating metabolic processes $[24,29]$.

The inflammasome is a heptamer formed by monomers containing Nod-like receptors (NLRs), the adaptor protein ASC (apoptosis-associated speck-like protein containing a caspase-recruitment domain), and the enzyme caspase-1. NLRs are characterized by a structure composed of a central domain that mediates nucleotide-binding and oligomerization (NOD or NBS domain), a C-terminal leucine-rich domain (LRR), and a variable $\mathrm{N}$-terminal region required for protein-protein interactions. When assembled as inflammasome, NLR activates caspase-1, which converts pro-IL- $1 \beta$ into active IL-1 $\beta[30,31]$.

In the human being, the NLR family consists of 22 members, classified in 4 subfamilies, NLRA, NLRB, NLRC, and NLRP, on basis of their N-terminal domain configuration. They interact with the inflammasome-associated proteins ASC and caspase-1 [32].

A member of the NLRP, named NLRP3, has been linked to metabolic stress, insulin resistance, and type 2 diabetes. NLRP3 inflammasome activation in obesity promotes macrophage-mediated $\mathrm{T}$ cell activation in adipose tissue and impairs insulin sensitivity creating a chronic proinflammatory state that impairs insulin sensitivity. Inflammasome activation can be induced by hyperglycemia, reactive oxygen species, palmitate, lipopolysaccharides, and uric acid, among other substances [24]. These findings highlight the potential molecular intervention in pathways regulating caspase- 1 activation for management of chronic inflammation [29-31, 33].

Recent studies show that a protein upregulated by glucose, the thioredoxin interacting protein (TXNIP), interacts with NLRP3, leading to IL-1 $\beta$ secretion and hampering of pancreatic $\beta$-cell function $[34,35]$.

\section{Inflammatory Cytokines}

The origin of inflammation during obesity and the underlying molecular mechanisms that explain its occurrence are not yet fully understood, but pro-inflammatory cytokines play a central role. In obesity, there are higher circulating concentrations of inflammatory cytokines than in lean beings, 
and it is believed that they play a role in causing insulin resistance. The main source of pro-inflammatory cytokines in obesity is the adipose tissue; they are mainly produced by infiltrating macrophages, although adipocytes play a role. In this way, blood concentrations of these cytokines are lowered following weight loss $[22,23]$. The main cytokines responsible of chronic inflammation are tumor necrosis factor- $\alpha$ (TNF $\alpha$ ), interleukin-6 (IL-6), and the inflammasome-activated IL-1 $\beta$ mentioned earlier.

TNF- $\alpha$ is a pleiotropic molecule that plays a central role in inflammation, immune system development, apoptosis, and lipid metabolism, with numerous effects in adipose tissue, including lipid metabolism and insulin signaling. Circulating TNF- $\alpha$ is increased in obesity and decreased with weight loss. TNF- $\alpha$ promotes the secretion of other powerful proinflammatory cytokine, IL-6, and reduces anti-inflammatory cytokines like adiponectin. TNF- $\alpha$ induces adipocytes apoptosis and promotes insulin resistance by the inhibition of the insulin receptor substrate 1 signaling pathway [36, 37].

IL-6 is a cytokine that plays important roles in acute phase reactions, inflammation, hematopoiesis, bone metabolism, and cancer progression. IL-6 regulates energy homeostasis and inflammation; it is capable of suppressing lipoprotein lipase activity, and it controls appetite and energy intake at hypothalamic level [38]. IL-6 is important in the transition from acute inflammation to chronic inflammatory disease. It contributes to chronic inflammation in conditions such as obesity, insulin resistance, inflammatory bowel disease, inflammatory arthritis, and sepsis when deregulated [39].

IL- $1 \beta$ is a pyrogenic cytokine. It is mainly produced by blood monocytes in response to infection, injury, or immunologic challenge; it causes fever, hypotension, and production of additional pro-inflammatory cytokines, such as IL-6. IL- $1 \beta$ is formed from its pro-IL- $1 \beta$ inactive precursor by the inflammasome. In this way, IL- $1 \beta$ has now emerged as a prominent instigator of the pro-inflammatory response in obesity [24].

Important advances have been reached in the last decade in the understanding the role of cytokines and the inflammasome in obesity, chronic inflammation, insulin resistance, and type 2 diabetes. However, further research is required to better understand the underlying mechanisms as they are potential intervention points in the search of new therapeutically modalities for these global health problems.

\section{Markers of Inflammation}

Several chronic diseases involve an inflammatory response characterized by the increase of cytokines and serum concentrations of acute-phase reactants (markers of active inflammation) such as fibrinogen, $\mathrm{C}$-reactive protein (CRP), complement, serum amyloid A, haptoglobin, sialic acid and low albumin concentrations [40]. Acute-phase reactants are synthesized in the liver, and its production is regulated by cytokines, including IL-6 and TNF-alpha [41-44]. The CRP, consideredes the classic sensitive acute-phase reactant, is a very sensitive systemic marker of inflammation, and its serum concentration increases rapidly in response to a variety of stimuli. This protein is present in low concentrations under normal conditions $[45,46]$.

Visceral adipose tissue may produce inflammatory mediators, which induce the production of acute-phase reactants in hepatocytes and endothelial cells [47]. In fact, because it has been shown that adipocytes express and secrete TNFalpha, adipose body mass may be an important mediator to explain the relation between obesity and inflammation [48]. Some studies have shown that abdominal adiposity is associated with elevation of CRP levels, independent of body mass index (BMI), which is a measure of general adiposity. The proportion of people with elevated hs-CRP was significantly higher in those individuals with abdominal adiposity than control subjects, although they had a similar BMI [49]. IL-6 is a pro-inflammatory cytokine synthesized by adipose tissue, endothelial cells, macrophages, and lymphocytes. The CRP is synthesized in the liver largely in response to IL- 6 stimuli [50]. Individuals with obesity are at increased risk for various chronic diseases, several of which are also characterized by elevated CRP concentrations. Because adipose tissue is a major source of pro-inflammatory cytokines such as IL-6 and TNF-alpha, both cytokines increase hepatic lipogenesis $[51,52]$ and trigger a systemic acute-phase response [41].

In recent years, it has been demonstrated that obesity is associated with low-grade inflammatory process characterized by the increase in circulating levels of pro-inflammatory cytokines such as IL-6, TNF-alpha, and acute-phase proteins (CRP and haptoglobin) in healthy obese subjects [53-56]. This phenomenon is also observed in obese children who have higher CRP levels than normal weight children [57]. Some studies have reported that weight loss, through diet, is associated with reduction in circulating levels of IL6, TNF-alpha, CRP, and other markers of inflammation, independently of age, sex, and BMI $[58,59]$. Similarly, weight reduction observed in subjects after gastric bypass shows decrease of CRP and IL-6 levels [60].

\section{Metabolic Syndrome}

The metabolic syndrome is characterized as the presence of three or more of the following features: obesity, hyperglycemia, hypertension, low HDL cholesterol levels, and/or hypertriglyceridemia [61-64]. Although pathogenic mechanisms are poorly understood, a central role has been attributed to the pro-inflammatory cytokines TNF-alpha [65] and IL-6 [66], since both are synthesized by adipose tissue. This syndrome has been associated with markers of inflammatory activity, such as CRP [67-75], IL-6 [76, 77], serum amyloid A $[78,79]$, and soluble adhesion molecules $[73,75,80,81]$.

Risk Factors. Low-grade chronic inflammation is associated with metabolic syndrome [82] and some features of insulin resistance [83]. Other studies have demonstrated significant correlation between CRP levels with features of the metabolic syndrome, including adiposity, hyperinsulinemia, insulin resistance, hypertriglyceridemia, and low HDL cholesterol $[84,85]$. Few studies have reported the association between 
CRP and development of metabolic syndrome $[50,86]$. In addition, it has been observed that elevated hs-CRP levels are associated with increased risk for incident cardiovascular events among individuals as having the metabolic syndrome [87]. Inflammation has been proposed as common part of different metabolic disturbances of insulin, glucose, and lipids that influence the underlying development of metabolic syndrome [50].

Also, it has shown that CRP adds independent prognostic information on severity of metabolic syndrome [87]. Given the evidence, it has been proposed that CRP is an additional component of metabolic syndrome [88]. In one study, it was reported that elevated levels of CRP ( $\geq 3 \mathrm{mg} / \mathrm{L})$ may increase the risk of metabolic syndrome mediated through obesity and factors related to insulin resistance [50].

Treatment. Observational studies have shown that dietary patterns similar to the Mediterranean diet, rich in fruit and vegetables and high in monounsaturated fats and fiber, resulted in decrease prevalence of the metabolic syndrome [89-91]. In addition, interventional studies also demonstrated a decrease in markers of inflammation in subjects with metabolic syndrome consuming Mediterranean diet and/or national dietary guidelines [92, 93].

Studies that evaluate markers of inflammation in individuals with metabolic syndrome are scarce; however, some have shown anti-inflammatory effects of statin therapy [94, 95]. Because subjects with metabolic syndrome exhibit increased inflammation, after therapeutic lifestyle changes, statins could be a therapeutic option.

\section{Cardiovascular Disease}

In the last years, different markers of inflammation (such as CRP, IL-6, and TNF-alpha, among others) have been studied in prediction of coronary events; on this regard, CRP is the most important marker for cardiovascular disease [96].

Risk Factors. Circulating elevated levels of inflammatory markers, such as CRP, TNF-alpha, and IL-6, are associated with increased risk of developing cardiovascular disease [97102]; even some acute-phase reactants may also contribute to their pathogenesis [103]. Though in mild degree, chronic elevation of CRP levels, even within normal value range, is an independent predictor of future cardiovascular events $[99,104]$. Stratified ranges of high-sensitivity CRP levels of $<1,1-3$, and $>3 \mathrm{mg} / \mathrm{L}$ correspond to low, moderate, and high risks for future cardiovascular events. Previously, some studies have found a significative association between CRP and cardiovascular risk $[105,106]$. This finding was observed for the first time over 50 years ago, where increased CRP level, after myocardial infarction, was identified as marker of poor prognostic [87]. Later, the European Concerted Action on Thrombosis and Disabilities Angina Pectoris Study Group reported that CRP concentrations were higher in the patients who had coronary events than in those without such events [107]. In addition, the Cholesterol and Recurrent Events Trial showed that elevated CRP levels are associated with major risk of coronary events after myocardial infarction
[108]. A growing body of evidence has corroborated that inflammation is a strong predictor of future cardiovascular events [96-99, 104, 109-114].

Furthermore, hsCRP is better marker of cardiovascular disease than others acute-phase reactants, cytokines, and soluble adhesion molecules [115]. Thus, supported by a large number of observational studies and meta-analyses, CRP is considered as a mediator of cardiovascular disease [116], independently of age, smoking, cholesterol levels, blood pressure, and diabetes among others traditional risk factors evaluated in the clinical setting [117]. Thus, CRP is one of the most well-documented emerging cardiovascular disease risk factors $[118,119]$.

Treatment. Some interventional studies using Mediterranean diet and others characterized by increased intake of mustard or soybean oil, fruits, vegetables, nuts, and whole grains reduced the rate of cardiovascular disease with significant anti-inflammatory effect $[120,121]$. Also, various observational and interventional studies found that intake of omega3 and omega- 6 fatty acids and alpha-linolenic acid resulted in lower risk of cardiovascular disease and lower concentrations of markers of inflammation [122-128]. Moreover, several studies have shown that statin therapy is associated with reduced inflammation and cardiovascular risk reduction $[108,129-141]$.

\section{Diabetes}

Several studies have shown that subclinical systemic inflammation, as measured by elevated levels of CRP and IL-6, predicts the development of diabetes [142-149]. In fact, IL6 may interfere with insulin signalling through induction of proteins that bind to the insulin receptor [150]. On this regard, a growing body of evidence supports the hypothesis that chronic systemic inflammation contributes to decrease of insulin sensitivity at peripheral tissues $[40,45,151,152]$.

Risk Factors. Several studies in healthy subjects have confirmed that elevated levels of CRP and cytokines IL- 6 and TNF-alpha are associated with insulin resistance $[84,85,153-$ 155]. In addition, it has been shown that in the individuals with impaired glucose tolerance $[156,157]$, the low-grade chronic inflammation is related to glucose metabolic disturbances.

It has been reported that TNF-alpha is overexpressed in the adipose and muscle tissues of obese and insulin-resistant nondiabetic subjects, overexpression that is positively correlated with insulin resistance $[48,158-160]$. Interestingly, circulating TNF-alpha levels are higher in type 2 diabetes [161-163] as compared with IFG/IGT [156]. In addition, several cross-sectional studies have shown an increase of CRP levels in patients with diabetes $[142,143,164]$ and the increase of CRP, IL-6, and TNF-alpha in subjects with IGT $[40,165]$.

Moreover, in obesity there are elevated levels of several kinases such as protein kinase $\mathrm{C}$ isoforms, I Kappa B Kinase$\beta$, and $c$-jun-terminal kinase, and these kinases have been implicated in alteration of insulin signaling by promoting serine phosphorylation of insulin receptor substrate which 
is associated with suppression of tyrosine phosphorylation of this substrate [166]. Also, various studies have demonstrated that nutrient excess and obesity are associated with elevated levels of free fatty acids, which can induce both insulin resistance in peripheral tissues and activation of innate immunity [28, 167-172].

Furthermore, it is difficult to set cut-point values to predict risk of development disease because intermediate values of CRP are at moderate risk for metabolic disturbances. However, it has been reported that patients with diabetes and CRP values $>3 \mathrm{mg} / \mathrm{L}$ have $51 \%$ higher risk of all-cause mortality and $44 \%$ higher risk of cardiovascular mortality than subjects with diabetes and CRP $<3 \mathrm{mg} / \mathrm{L}$ of similar age and sex, independently of classical risk factors such as lipids, blood pressure, and glycemia [173].

Treatment. In clinical field, there are different therapeutic options, such as genetic, biochemical, and pharmacological targeting of inflammatory signalling pathways improving insulin action, a central problem in the pathophysiology of type 2 diabetes [174]. Existing evidence about inhibiting specific inflammatory kinases pathway improves insulin action in animal models $[175,176]$. Pharmacological therapeutics using thiazolidinediones exhibited anti-inflammatory effects inhibiting both adipocyte and macrophage function in obesity and type 2 diabetes [177]. Various clinical studies, using anti-inflammatory drugs to treat type 2 diabetes and even prediabetes, showed improvements in beta-cell function and insulin sensitivity, reducing glucose levels [34, 178-182]. In addition, others studies in patients with type 2 diabetes taking statins have demonstrated a beneficial and additive effect on markers of inflammation [183-186], which could be an alternative therapeutic for this disease; however, the clinical practice recommendations should be considered about the appropriate use of statin therapy because basic studies have documented controversial results regarding the beneficial and adverse effects on insulin secretion and sensitivity [187].

\section{Conclusion}

The origin of inflammation during obesity and the underlying molecular mechanisms that explain its occurrence are not still fully understood, but pro-inflammatory cytokines play a central role. In obesity, there are higher circulating concentrations of inflammatory cytokines than in lean beings, and it is believed that they play a role in causing insulin resistance. The main source of proinflammatory cytokines in obesity is the adipose tissue; they are mainly produced by infiltrating macrophages, although adipocytes play a role. Obesity is a consequence of many risk factors, as increased energy consumption and reduced physical exercise. Many problems ecist in patients with obesity, as cardiovascular disease, diabetes, metabolic syndrome, and NAFLD, among others, predicting the risk of future cardiovascular events and mortality. Different mechanisms, including antioxidant, anti-inflammatory, fiber diet, and antiestrogenic processes, have been proposed to explain the protective nature of certain dietary components, particularly, components of Mediterranean diet which could be an important therapeutic lifestyle change which allows to avoid the development of metabolic diseases.

\section{References}

[1] M. M. Finucane, G. A. Stevens, M. J. Cowan et al., "National, regional, and global trends in body-mass index since 1980: systematic analysis of health examination surveys and epidemiological studies with 960 country-years and 9.1 million participants," The Lancet, vol. 377, no. 9765, pp. 557-567, 2011.

[2] E. S. Ford and A. H. Mokdad, "Epidemiology of obesity in the Western Hemisphere," The Journal of Clinical Endocrinology and Metabolism, vol. 93, pp. S1-S8, 2008.

[3] National Institutes of Health, Clinical Guidelines on the Identification, Evaluation, and Treatment of Overweight and Obesity in Adults, U.S. Department of Health and Human Services, Bethesda, Md, USA, 1998.

[4] R. J. Kuczmarski, K. M. Flegal, S. M. Campbell, and C. L. Johnson, "Increasing prevalence of overweight among US adults: the National Health and Nutrition Examination Surveys, 1960 to 1991," Journal of the American Medical Association, vol. 272, no. 3, pp. 205-211, 1994.

[5] R. P. Troiano, K. M. Flegal, R. J. Kuczmarski, S. M. Campbell, and C. L. Johnson, "Overweight prevalence and trends for children and adolescents: the National Health and Nutrition Examination Surveys, 1963 to 1991," Archives of Pediatrics and Adolescent Medicine, vol. 149, no. 10, pp. 1085-1091, 1995.

[6] D. S. Freedman, L. K. Khan, M. K. Serdula, D. A. Galuska, and W. H. Dietz, "Trends and correlates of class 3 obesity in the United States from 1990 through 2000," Journal of the American Medical Association, vol. 288, no. 14, pp. 1758-1761, 2002.

[7] H. M. Orpana, J. M. Berthelot, M. S. Kaplan, D. H. Feeny, B. McFarland, and N. A. Ross, "BMI and mortality: results from a national longitudinal study of canadian adults," Obesity, vol. 18, no. 1, pp. 214-218, 2009.

[8] G. S. Hotamisligil, "Inflammation and metabolic disorders," Nature, vol. 444, no. 7121, pp. 860-867, 2006.

[9] P. M. Ridker, J. E. Buring, J. Shih, M. Matias, and C. H. Hennekens, "Prospective study of C-reactive protein and the risk of future cardiovascular events among apparently healthy women," Circulation, vol. 98, no. 8, pp. 731-733, 1998.

[10] M. S. Kaplan, N. Huguet, J. T. Newsom, B. H. McFarland, and J. Lindsay, "Prevalence and correlates of overweight and obesity among older adults: findings from the Canadian National Population Health Survey," Journals of Gerontology A, vol. 58, no. 11, pp. 1018-1030, 2003.

[11] L. A. Adams, J. F. Lymp, J. S. Sauver et al., "The natural history of nonalcoholic fatty liver disease: a population-based cohort study," Gastroenterology, vol. 129, no. 1, pp. 113-121, 2005.

[12] P. Angulo, "Medical progress: nonalcoholic fatty liver disease," The New England Journal of Medicine, vol. 346, no. 16, pp. 12211231, 2002.

[13] S. Bellentani and M. Marino, "Epidemiology and natural history of non-alcoholic fatty liver disease (NAFLD)," Annals of Hepatology, vol. 8, supplement 1, pp. S4-S8, 2009.

[14] C. E. Ruhl and J. E. Everhart, "Trunk fat is associated with increased serum levels of alanine aminotransferase in the United States," Gastroenterology, vol. 138, no. 4, pp. 1346.e31356.e3, 2010.

[15] H. Rodriguez-Hernandez, M. Cervantes-Alvarez, M. Rodriguez- Moran, and F. Guerrero-Romero, "Decrease 
of aminotransferase levels in obese women is related to body weight reduction, irrespective of type of diet," Annals of Hepatology, vol. 10, pp. 486-492, 2011.

[16] H. Rodriguez-Hernandez, U. A. Morales-Amaya, R. RosalesValdéz, F. Rivera-Hinojosa, M. Rodriguez-Moran, and F. Guerrero-Romero, "Adding cognitive behavioural treatment to either low-carbohydrate or low-fat diets: differential short-term effects," British Journal of Nutrition, vol. 102, no. 12, pp. 18471853, 2009.

[17] M. Stepanova and Z. M. Younoussi, "Independent association between nonalcoholic fatty liver disease and cardiovascular disease in US population," Clinical Gastroenterology and Hepatology, vol. 10, pp. 646-650, 2012.

[18] H. Kuper, A. Tzonou, and E. Kakalamani, "Tobacco smoking, alcohol consumption and their interaction in the causation of hepatocelular carcinoma," International Journal of Cancer, vol. 85, pp. 498-502, 2000.

[19] D. Trichopoulos, C. Bamia, and P. Lagiou, "Hepatocelular carcinoma risk factors and disease burden in a European cohort: a nested case-control study," Journal of the National Cancer Institute, vol. 103, pp. 1686-1695, 2011.

[20] N. D. Freedman and J. A. Marrero, "Can dietary fish intake prevent liver cancer?” Gastroenterology, vol. 142, pp. 1411-1413, 2012.

[21] L. J. Su, S. Mahabir, G. L. Ellison, L. A. McGuinn, and B. C. Reid, "Epigenetic contributions to the relationship between cancer and dietary intake of nutrients, bioactive food, components, and environmental toxicants," Nutrigenomics, vol. 2, pp. 1-12, 2012.

[22] M. F. Gregor and G. S. Hotamisligil, "Inflammatory mechanisms in obesity," Annual Review of Immunology, vol. 29, pp. 415-445, 2011.

[23] E. Faloia, G. Michetti, M. de Robertis, M. P. Luconi, G. Furlani, and M. Boscaro, "Inflammation as a link between obesity and metabolic syndrome," Journal of Nutrition and Metabolism, vol. 2012, Article ID 476380, 7 pages, 2012.

[24] R. Stienstra, C. J. Tack, T. D. Kanneganti, L. A. Joosten, and M. G. Netea, "The inflammasome puts obesity in the danger zone," Cell Metabolism, vol. 15, pp. 10-18, 2012.

[25] G. Solinas and M. Karin, "JNK1 and IKK $\beta$ : molecular links between obesity and metabolic dysfunction," The FASEB Journal, vol. 24, no. 8, pp. 2596-2611, 2010.

[26] S. Boura-Halfon and Y. Zick, "Phosphorylation of IRS proteins, insulin action, and insulin resistance," American Journal of Physiology, vol. 296, no. 4, pp. E581-E591, 2009.

[27] K. Schroder, R. Zhou, and J. Tschopp, “The NLRP3 inflammasome: a sensor for metabolic danger?” Science, vol. 327, no. 5963, pp. 296-300, 2010.

[28] H. Shi, M. V. Kokoeva, K. Inouye, I. Tzameli, H. Yin, and J. S. Flier, "TLR4 links innate immunity and fatty acid-induced insulin resistance," The Journal of Clinical Investigation, vol. 116, no. 11, pp. 3015-3025, 2006.

[29] M. Lamkanfi and T. D. Kanneganti, "The inflammasome: a remote control for metabolic syndrome," Cell Research, vol. 22, pp. 1095-1098, 2012.

[30] L. D. Church, G. P. Cook, and M. F. McDermott, "Primer: inflammasomes and interleukin $1 \beta$ in inflammatory disorders," Nature Clinical Practice Rheumatology, vol. 4, no. 1, pp. 34-42, 2008.

[31] M. Dagenais, J. Dupaul-Chicoine, and M. Saleh, "Function of NOD-like receptors in immunity and disease," Current Opinion in Investigational Drugs, vol. 11, no. 11, pp. 1246-1255, 2010.
[32] M. Dagenais, A. Skeldon, and M. Saleh, "The inflammasome: in memory of Dr. Jurg Tschopp," Cell Death and Differentiation, vol. 19, pp. 5-12, 2012.

[33] B. Vandanmagsar, Y. H. Youm, A. Ravussin et al., "The NLRP3 inflammasome instigates obesity-induced inflammation and insulin resistance," Cell Death and Differentiation, vol. 17, pp. 179-188, 2011.

[34] C. M. Larsen, M. Faulenbach, A. Vaag et al., "Interleukin1-receptor antagonist in type 2 diabetes mellitus," The New England Journal of Medicine, vol. 356, no. 15, pp. 1517-1526, 2007.

[35] R. Zhou, A. Tardivel, B. Thorens, I. Choi, and J. Tschopp, "Thioredoxin-interacting protein links oxidative stress to inflammasome activation," Nature Immunology, vol. 11, no. 2, pp. 136-140, 2010.

[36] G. S. Hotamisligil, P. Peraldi, A. Budavari, R. Ellis, M. F. White, and B. M. Spiegelman, "IRS-1-mediated inhibition of insulin receptor tyrosine kinase activity in TNF- $\alpha$ - and obesity-induced insulin resistance," Science, vol. 271, no. 5249, pp. 665-668, 1996.

[37] B. Wang and P. Trayhurn, "Acute and prolonged effects of TNF- $\alpha$ on the expression and secretion of inflammation-related adipokines by human adipocytes differentiated in culture," Pflugers Archiv European Journal of Physiology, vol. 452, no. 4, pp. 418-427, 2006.

[38] K. Stenlöf, I. Wernstedt, T. Fjällman, V. Wallenius, K. Wallenius, and J. O. Jansson, "Interleukin-6 levels in the central nervous system are negatively correlated with fat mass in overweight/obese subjects," Journal of Clinical Endocrinology and Metabolism, vol. 88, no. 9, pp. 4379-4383, 2003.

[39] W. E. Naugler and M. Karin, "The wolf in sheep's clothing: the role of interleukin-6 in immunity, inflammation and cancer," Trends in Molecular Medicine, vol. 14, no. 3, pp. 109-119, 2008.

[40] J. C. Pickup, "Inflammation and activated innate immunity in the pathogenesis of type 2 diabetes," Diabetes Care, vol. 27, no. 3, pp. 813-823, 2004.

[41] H. Baumann and J. Gauldie, "The acute phase response," Immunology Today, vol. 15, no. 2, pp. 74-80, 1994.

[42] C. Gabay and I. Kushner, "Acute-phase proteins and other systemic responses to inflammation," The New England Journal of Medicine, vol. 340, no. 6, pp. 448-454, 1999.

[43] J. S. Yudkin, M. Kumari, S. E. Humphries, and V. MohamedAli, "Inflammation, obesity, stress and coronary heart disease: is interleukin-6 the link?" Atherosclerosis, vol. 148, no. 2, pp. 209214, 2000.

[44] J. S. Yudkin, "Adipose tissue, insulin action and vascular disease: inflammatory signals," International Journal of Obesity, vol. 27, supplement 3, pp. S25-S28, 2003.

[45] T. A. Pearson, G. A. Mensah, R. W. Alexander et al., "Markers of inflammation and cardiovascular disease: application to clinical and public health practice: a statement for healthcare professionals from the centers for disease control and prevention and the American Heart Association," Circulation, vol. 107, no. 3, pp. 499-511, 2003.

[46] M. B. Pepys and G. M. Hirschfield, "C-reactive protein: a critical update," The Journal of Clinical Investigation, vol. 111, no. 12, pp. 1805-1812, 2003.

[47] M. Jacobs, M. M. J. van Greevenbroek, C. J. H. van der Kallen et al., "Low-grade inflammation can partly explain the association between the metabolic syndrome and either coronary artery disease or severity of peripheral arterial disease: the CODAM study," European Journal of Clinical Investigation, vol. 39, no. 6, pp. 437-444, 2009. 
[48] P. A. Kern, M. Saghizadeh, J. M. Ong, R. J. Bosch, R. Deem, and R. B. Simsolo, "The expression of tumor necrosis factor in human adipose tissue. Regulation by obesity, weight loss, and relationship to lipoprotein lipase," The Journal of Clinical Investigation, vol. 95, no. 5, pp. 2111-2119, 1995.

[49] E. Lapice, S. Maione, L. Patti et al., "Abdominal adiposity is associated with elevated C-reactive protein independent of BMI in healthy nonobese people," Diabetes Care, vol. 32, no. 9, pp. 1734-1736, 2009.

[50] D. E. Laaksonen, L. Niskanen, K. Nyyssönen et al., "C-reactive protein and the development of the metabolic syndrome and diabetes in middle-aged men," Diabetologia, vol. 47, no. 8, pp. 1402-1410, 2004.

[51] K. R. Feingold and C. Grunfeld, "Role of cytokines in inducing hyperlipidemia," Diabetes, vol. 41, supplement 2, pp. 97-101, 1992.

[52] G. S. Hotamisligil and B. M. Spiegelman, "Tumor necrosis factor $\alpha$ : a key component of the obesity-diabetes link," Diabetes, vol. 43, no. 11, pp. 1271-1278, 1994.

[53] F. X. Pi-Sunyer, "The obesity epidemic: pathophysiology and consequences of obesity," Obesity Research, vol. 10, supplement 10, pp. 97S-104S, 2002.

[54] A. E. Caballero, "Endothelial dysfunction in obesity and insulin resistance: a road to diabetes and heart disease," Obesity Research, vol. 11, no. 11, pp. 1278-1289, 2003.

[55] A. H. Berg and P. E. Scherer, "Adipose tissue, inflammation, and cardiovascular disease," Circulation Research, vol. 96, no. 9, pp. 939-949, 2005.

[56] D. C. W. Lau, B. Dhillon, H. Yan, P. E. Szmitko, and S. Verma, "Adipokines: molecular links between obesity and atheroslcerosis," American Journal of Physiology, vol. 288, no. 5, pp. H2031H2041, 2005.

[57] M. Visser, L. M. Bouter, G. M. McQuillan, M. H. Wener, and T. B. Harris, "Low-grade systemic inflammation in overweight children," Pediatrics, vol. 107, no. 1, pp. 1-6, 2001.

[58] G. Nicoletti, G. Giugliano, A. Pontillo et al., "Effect of a multidisciplinary program of weight reduction on endothelial functions in obese women," Journal of Endocrinological Investigation, vol. 26, no. 3, pp. RC5-RC8, 2003.

[59] L. K. Heilbronn, M. Noakes, and P. M. Clifton, "Energy restriction and weight loss on very-low-fat diets reduce Creactive protein concentrations in obese, healthy women," Arteriosclerosis, Thrombosis, and Vascular Biology, vol. 21, no. 6, pp. 968-970, 2001.

[60] H. P. Kopp, C. W. Kopp, A. Festa et al., "Impact of weight loss on inflammatory proteins and their association with the insulin resistance syndrome in morbidly obese patients," Arteriosclerosis, Thrombosis, and Vascular Biology, vol. 23, no. 6, pp. 10421047, 2003.

[61] G. M. Reaven, "Role of insulin resistance in human disease," Diabetes, vol. 37, no. 12, pp. 1595-1607, 1988.

[62] E. Ferrannini, S. M. Haffner, B. D. Mitchell, and M. P. Stern, "Hyperinsulinaemia: the key feature of cardiovascular and metabolic syndrome," Diabetologia, vol. 34, no. 6, pp. 416-422, 1991.

[63] R. S. Gray, R. R. Fabsitz, L. D. Cowan, E. T. Lee, B. V. Howard, and P. J. Savage, "Risk factor clustering in the insulin resistance syndrome. The strong heart study," American Journal of Epidemiology, vol. 148, no. 9, pp. 869-878, 1998.

[64] M. Carantoni, G. Zuliani, S. Volpato et al., "Relationships between fasting plasma insulin, anthropometrics, and metabolic parameters in a very old healthy population," Metabolism, vol. 47, no. 5, pp. 535-540, 1998.

[65] G. S. Hotamisligil, N. S. Shargill, and B. M. Spiegelman, "Adipose expression of tumor necrosis factor- $\alpha$ : direct role in obesity-linked insulin resistance," Science, vol. 259, no. 5091, pp. 87-91, 1993.

[66] V. Mohamed-Ali, S. Goodrick, A. Rawesh et al., "Subcutaneous adipose tissue releases interleukin-6, but not tumor necrosis factor- $\alpha$, in vivo," Journal of Clinical Endocrinology and Metabolism, vol. 82, no. 12, pp. 4196-4200, 1997.

[67] R. Anty, S. Bekri, N. Luciani et al., “The inflammatory C-reactive protein is increased in both liver and adipose tissue in severely obese patients independently from metabolic syndrome, type 2 diabetes, and NASH," American Journal of Gastroenterology, vol. 101, no. 8, pp. 1824-1833, 2006.

[68] P. Calabro, D. W. Chang, J. T. Willerson, and E. T. H. Yeh, "Release of C-reactive protein in response to inflammatory cytokines by human adipocytes: linking obesity to vascular inflammation," Journal of the American College of Cardiology, vol. 46, no. 6, pp. 1112-1113, 2005.

[69] H. Florez, S. Castillo-Florez, A. Mendez et al., "C-reactive protein is elevated in obese patients with the metabolic syndrome," Diabetes Research and Clinical Practice, vol. 71, no. 1, pp. 92-100, 2006.

[70] A. S. González, D. B. Guerrero, M. B. Soto, S. P. Díaz, M. Martinez-Olmos, and O. Vidal, "Metabolic syndrome, insulin resistance and the inflammation markers $\mathrm{C}$-reactive protein and ferritin," European Journal of Clinical Nutrition, vol. 60, no. 6, pp. 802-809, 2006.

[71] N. Ouchi, S. Kihara, T. Funahashi et al., "Reciprocal association of C-reactive protein with adiponectin in blood stream and adipose tissue," Circulation, vol. 107, no. 5, pp. 671-674, 2003.

[72] G. P. van Guilder, G. L. Hoetzer, J. J. Greiner, B. L. Stauffer, and C. A. DeSouza, "Influence of metabolic syndrome on biomarkers of oxidative stress and inflammation in obese adults," Obesity, vol. 14, no. 12, pp. 2127-2131, 2006.

[73] E. Ingelsson, J. Hulthe, and L. Lind, "Inflammatory markers in relation to insulin resistance and the metabolic syndrome," European Journal of Clinical Investigation, vol. 38, no. 7, pp. 502509, 2008.

[74] Y. Matsuo, T. Hashizume, S. Shioji, and T. Akasaka, "Metabolic syndrome is strongly associated with chronic subclinical inflammation in patients achieving optimal low-density lipoprotein-cholesterol levels in secondary prevention of cardiovascular disease," Circulation Journal, vol. 72, no. 12, pp. 2046-2050, 2008.

[75] G. Kressel, B. Trunz, A. Bub et al., "Systemic and vascular markers of inflammation in relation to metabolic syndrome and insulin resistance in adults with elevated atherosclerosis risk," Atherosclerosis, vol. 202, no. 1, pp. 263-271, 2009.

[76] R. Bataille, B. Klein, and I. Kushner, "C-reactive protein levels as a direct indicator of interleukin-6 levels in humans in vivo," Arthritis and Rheumatism, vol. 35, no. 8, pp. 982-984, 1992.

[77] P. C. Heinrich, J. V. Castell, and T. Andus, "Interleukin-6 and the acute phase response," Biochemical Journal, vol. 265, no. 3, pp. 621-636, 1990.

[78] J. V. Castell, M. J. Gomez-Lechon, M. David et al., "Interleukin6 is the major regulator of acute phase protein synthesis in adult human hepatocytes," FEBS Letters, vol. 242, no. 2, pp. 237-239, 1989. 
[79] J. V. Castell, M. J. Gomes-Lechon, M. David, T. Hirano, T. Kishimoto, and P. C. Heinrich, "Recombinant human interleukin6 (IL-6/BSF-2/HSF) regulates the synthesis of acute phase proteins in human hepatocytes," FEBS Letters, vol. 232, no. 2, pp. 347-350, 1988.

[80] K. K. Koh, S. H. Han, and M. J. Quon, "Inflammatory markers and the metabolic syndrome: insights from therapeutic interventions," Journal of the American College of Cardiology, vol. 46, no. 11, pp. 1978-1985, 2005.

[81] W. H. Haught, M. Mansour, R. Rothlein et al., "Alterations in circulating intercellular adhesion molecule-1 and L-selectin: further evidence for chronic inflammation in ischemic heart disease," American Heart Journal, vol. 132, no. 1 I, pp. 1-8, 1996.

[82] D. E. Laaksonen, L. Niskanen, K. Punnonen et al., "Sex hormones, inflammation and the metabolic syndrome: a population-based study," European Journal of Endocrinology, vol. 149 , no. 6, pp. 601-608, 2003.

[83] J. M. Fernández-Real and W. Ricart, "Insulin resistance and chronic cardiovascular inflammatory syndrome," Endocrine Reviews, vol. 24, no. 3, pp. 278-301, 2003.

[84] J. S. Yudkin, C. D. A. Stehouwer, J. J. Emeis, and S. W. Coppack, "C-reactive protein in healthy subjects: associations with obesity, insulin resistance, and endothelial dysfunction: a potential role for cytokines originating from adipose tissue?" Arteriosclerosis, Thrombosis, and Vascular Biology, vol. 19, no. 4, pp. 972-978, 1999.

[85] A. Festa, R. D’Agostino, G. Howard, L. Mykkänen, R. P. Tracy, and S. M. Haffner, "Chronic subclinical inflammation as part of the insulin resistance syndrome: the insulin resistance atherosclerosis study (IRAS)," Circulation, vol. 101, no. 1, pp. 4247, 2000.

[86] T. S. Han, N. Sattar, K. Williams, C. Gonzalez-Villalpando, M. E. J. Lean, and S. M. Haffner, "Prospective study of C-reactive protein in relation to the development of diabetes and metabolic syndrome in the Mexico City diabetes study," Diabetes Care, vol. 25, no. 11, pp. 2016-2021, 2002.

[87] P. M. Ridker, J. E. Buring, N. R. Cook, and N. Rifai, "Creactive protein, the metabolic syndrome, and risk of incident cardiovascular events: an 8-year follow-up of 14719 initially healthy American women," Circulation, vol. 107, no. 3, pp. 391$397,2003$.

[88] N. Sattar, A. Gaw, O. Scherbakova et al., "Metabolic syndrome with and without C-reactive protein as a predictor of coronary heart disease and diabetes in the West of Scotland Coronary Prevention Study," Circulation, vol. 108, no. 4, pp. 414-419, 2003.

[89] D. E. M. Williams, A. T. Prevost, M. J. Whichelow, B. D. Cox, N. E. Day, and N. J. Wareham, "A cross-sectional study of dietary patterns with glucose intolerance and other features of the metabolic syndrome," British Journal of Nutrition, vol. 83, no. 3, pp. 257-266, 2000.

[90] N. M. McKeown, J. B. Meigs, S. Liu, E. Saltzman, P. W. F. Wilson, and P. F. Jacques, "Carbohydrate nutrition, insulin resistance, and the prevalence of the metabolic syndrome in the Framingham Offspring Cohort," Diabetes Care, vol. 27, no. 2, pp. 538-546, 2004.

[91] D. B. Panagiotakos, C. Pitsavos, C. Chrysohoou et al., "Impact of lifestyle habits on the prevalence of the metabolic syndrome among Greek adults from the ATTICA study," American Heart Journal, vol. 147, no. 1, pp. 106-112, 2004.

[92] K. Esposito, R. Marfella, M. Ciotola et al., "Effect of a Mediterranean-style diet on endothelial dysfunction and markers of vascular inflammation in the metabolic syndrome: a randomized trial," Journal of the American Medical Association, vol. 292, no. 12, pp. 1440-1446, 2004.

[93] N. Ahluwalia, V. A. Andreeva, E. Kesse-Guyot, and S. Hercberg, "Dietary patterns, inflammation and the metabolic syndrome," Diabetes \& Metabolism, 2012.

[94] I. Lazich, P. Sarafidis, E. de Guzman, A. Patel, R. Oliva, and G. Bakris, "Effects of combining simvastatin with rosiglitazone on inflammation, oxidant stress and ambulatory blood pressure in patients with the metabolic syndrome: the SIROCO study," Diabetes, Obesity and Metabolism, vol. 14, no. 2, pp. 181-186, 2012.

[95] S. Devaraj, E. Chan, and I. Jialal, "Direct demonstration of an antiinflammatory effect of simvastatin in subjects with the metabolic syndrome," Journal of Clinical Endocrinology and Metabolism, vol. 91, no. 11, pp. 4489-4496, 2006.

[96] P. M. Ridker, N. Rifai, L. Rose, J. E. Buring, and N. R. Cook, "Comparison of C-reactive protein and low-density lipoprotein cholesterol levels in the prediction of first cardiovascular events," The New England Journal of Medicine, vol. 347, no. 20, pp. 1557-1565, 2002.

[97] P. M. Ridker, M. Cushman, M. J. Stampfer, R. P. Tracy, and C. H. Hennekens, "Inflammation, aspirin, and the risk of cardiovascular disease in apparently healthy men," The New England Journal of Medicine, vol. 336, no. 14, pp. 973-979, 1997.

[98] R. P. Tracy, R. N. Lemaitre, B. M. Psaty et al., "Relationship of C-reactive protein to risk of cardiovascular disease in the elderly: results from the Cardiovascular Health Study and the Rural Health Promotion Project," Arteriosclerosis, Thrombosis, and Vascular Biology, vol. 17, no. 6, pp. 1121-1127, 1997.

[99] W. Koenig, M. Sund, M. Fröhlich et al., "C-reactive protein, a sensitive marker of inflammation, predicts future risk of coronary heart disease in initially healthy middle-aged men: results from the MONICA (monitoring trends and determinants in cardiovascular disease) Augsburg cohort study, 1984 to 1992," Circulation, vol. 99, no. 2, pp. 237-242, 1999.

[100] M. Cesari, B. W. J. H. Penninx, A. B. Newman et al., "Inflammatory markers and onset of cardiovascular events: results from the Health ABC Study," Circulation, vol. 108, no. 19, pp. 23172322, 2003.

[101] P. M. Ridker, N. Rifai, M. J. Stampfer, and C. H. Hennekens, "Plasma concentration of interleukin- 6 and the risk of future myocardial infarction among apparently healthy men," Circulation, vol. 101, no. 15, pp. 1767-1772, 2000.

[102] P. M. Ridker, N. Rifai, M. Pfeffer, F. Sacks, S. Lepage, and E. Braunwald, "Elevation of tumor necrosis factor- $\alpha$ and increased risk of recurrent coronary events after myocardial infarction," Circulation, vol. 101, no. 18, pp. 2149-2153, 2000.

[103] D. C. W. Lau, B. Dhillon, H. Yan, P. E. Szmitko, and S. Verma, "Adipokines: molecular links between obesity and atheroslcerosis," American Journal of Physiology, vol. 288, no. 5, pp. H2031H2041, 2005.

[104] P. M. Ridker, C. H. Hennekens, J. E. Buring, and N. Rifai, "C-reactive protein and other markers of inflammation in the prediction of cardiovascular disease in women," The New England Journal of Medicine, vol. 342, no. 12, pp. 836-843, 2000.

[105] L. H. Kuller, J. E. Eichner, T. J. Orchard, G. A. Grandits, L. McCallum, and R. P. Tracy, "The relation between serum albumin levels and risk of coronary heart disease in the multiple risk factor intervention trial," American Journal of Epidemiology, vol. 134, no. 11, pp. 1266-1277, 1991.

[106] G. Liuzzo, L. M. Biasucci, J. R. Gallimore et al., "The prognostic value of $\mathrm{C}$-reactive protein and serum amyloid A protein in 
severe unstable angina," The New England Journal of Medicine, vol. 331, no. 7, pp. 417-424, 1994.

[107] S. G. Thompson, J. Kienast, S. D. M. Pyke et al., "Hemostatic factors and the risk of myocardial infarction or sudden death in patients with angina pectoris," The New England Journal of Medicine, vol. 332, no. 10, pp. 635-641, 1995.

[108] P. M. Ridker, N. Rifai, M. A. Pfeffer et al., "Inflammation, pravastatin, and the risk of coronary events after myocardial infarction in patients with average cholesterol levels," Circulation, vol. 98, no. 9, pp. 839-844, 1998.

[109] P. M. Ridker, R. J. Glynn, and C. H. Hennekens, "C-reactive protein adds to the predictive value of total and HDL cholesterol in determining risk of first myocardial infarction," Circulation, vol. 97, no. 20, pp. 2007-2011, 1998.

[110] J. Danesh, P. Whincup, M. Walker et al., "Low grade inflammation and coronary heart disease: prospective study and updated meta-analyses," British Medical Journal, vol. 321, no. 7255, pp. 199-204, 2000.

[111] C. M. Albert, J. Ma, N. Rifai, M. J. Stampfer, and P. M. Ridker, "Prospective study of C-reactive protein, homocysteine, and plasma lipid levels as predictors of sudden cardiac death," Circulation, vol. 105, no. 22, pp. 2595-2599, 2002.

[112] L. H. Kuller, R. P. Tracy, J. Shaten, and E. N. Meilahn, "Relation of C-reactive protein and coronary heart disease in the MRFIT nested case-control study," American Journal of Epidemiology, vol. 144, no. 6, pp. 537-547, 1996.

[113] M. A. Mendall, D. P. Strachan, B. K. Butland et al., "C-reactive protein: relation to total mortality, cardiovascular mortality and cardiovascular risk factors in men," European Heart Journal, vol. 21, no. 19, pp. 1584-1590, 2000.

[114] T. B. Harris, L. Ferrucci, R. P. Tracy et al., "Associations of elevated interleukin- 6 and C-reactive protein levels with mortality in the elderly," American Journal of Medicine, vol. 106, no. 5, pp. 506-512, 1999.

[115] W. L. Roberts, "CDC/AHA workshop on markers of inflammation and cardiovascular disease: application to clinical and public health practice: laboratory tests available to asses inflammation-performance and standardization: a background paper," Circulation, vol. 110, no. 25, pp. e572-e576, 2004.

[116] R. J. Bisoendial, S. M. Boekholdt, M. Vergeer, E. S. G. Stroes, and J. J. P. Kastelein, "C-reactive protein is a mediator of cardiovascular disease," European Heart Journal, vol. 31, no. 17, pp. 2087-2091, 2010.

[117] P. W. Wilson, M. Pencina, P. Jacques, J. Selhub, R. D’Agostino, and C. J. O'Donnell, "C-reactive protein and reclassification of cardiovascular risk in the Framingham Heart Study," Circulation, vol. 1, no. 2, pp. 92-97, 2008.

[118] B. Keavney, " $\mathrm{C}$ reactive protein and the risk of cardiovascular disease," British Medical Journal, vol. 342, article d144, 2011.

[119] S. P. Fortmann, E. Ford, M. H. Criqui et al., "CDC/AHA workshop on markers of inflammation and cardiovascular disease: application to clinical and public health practice: report from the population science discussion group," Circulation, vol. 110, no. 25, pp. e554-e559, 2004.

[120] M. de Lorgeril, P. Salen, J. L. Martin, I. Monjaud, J. Delaye, and N. Mamelle, "Mediterranean diet, traditional risk factors, and the rate of cardiovascular complications after myocardial infarction: final report of the Lyon Diet Heart Study," Circulation, vol. 99, no. 6, pp. 779-785, 1999.

[121] R. B. Singh, G. Dubnov, M. A. Niaz et al., "Effect of an IndoMediterranean diet on progression of coronary artery disease in high risk patients (Indo-Mediterranean Diet Heart Study): a randomised single-blind trial," The Lancet, vol. 360, no. 9344, pp. 1455-1461, 2002.

[122] T. Pischon, S. E. Hankinson, G. S. Hotamisligil, N. Rifai, W. C. Willett, and E. B. Rimm, "Habitual dietary intake of n-3 and n-6 fatty acids in relation to inflammatory markers among US men and women," Circulation, vol. 108, no. 2, pp. 155-160, 2003.

[123] L. Djoussé, J. S. Pankow, J. H. Eckfeldt et al., "Relation between dietary linolenic acid and coronary artery disease in the National Heart, Lung, and Blood Institute Family Heart study," American Journal of Clinical Nutrition, vol. 74, no. 5, pp. 612-619, 2001.

[124] E. Lopez-Garcia, M. B. Schulze, J. E. Manson et al., "Consumption of (n-3) fatty acids is related to plasma biomarkers of inflammation and endothelial activation in women," Journal of Nutrition, vol. 134, no. 7, pp. 1806-1811, 2004.

[125] T. Madsen, H. A. Skou, V. E. Hansen et al., "C-reactive protein, dietary n-3 fatty acids, and the extent of coronary artery disease," American Journal of Cardiology, vol. 88, no. 10, pp. 1139-1142, 2001.

[126] G. Zhao, T. D. Etherton, K. R. Martin, S. G. West, P. J. Gillies, and P. M. Kris-Etherton, "Dietary $\alpha$-linolenic acid reduces inflammatory and lipid cardiovascular risk factors in hypercholesterolemic men and women," Journal of Nutrition, vol. 134, no. 11, pp. 2991-2997, 2004.

[127] L. S. Rallidis, G. Paschos, G. K. Liakos, A. H. Velissaridou, G. Anastasiadis, and A. Zampelas, "Dietary $\alpha$-linolenic acid decreases C-reactive protein, serum amyloid A and interleukin6 in dyslipidaemic patients," Atherosclerosis, vol. 167, no. 2, pp. 237-242, 2003.

[128] W. J. E. Bemelmans, J. D. Lefrandt, E. J. M. Feskens et al., "Increased $\alpha$-linolenic acid intake lowers $\mathrm{C}$-reactive protein, but has no effect on markers of atherosclerosis," European Journal of Clinical Nutrition, vol. 58, no. 7, pp. 1083-1089, 2004.

[129] P. M. Ridker, E. Danielson, F. A. H. Fonseca et al., "Rosuvastatin to prevent vascular events in men and women with elevated Creactive protein," The New England Journal of Medicine, vol. 359, no. 21, pp. 2195-2207, 2008.

[130] J. Shepherd, S. M. Cobbe, I. Ford et al., "Prevention of coronary heart disease with pravastatin in men with hypercholesterolemia," The New England Journal of Medicine, vol. 333, no. 20, pp. 1301-1307, 1995.

[131] J. R. Downs, M. Clearfield, S. Weis et al., "Primary prevention of acute coronary events with lovastatin in men and women with average cholesterol levels: results of AFCAPS/TexCAPS," Journal of the American Medical Association, vol. 279, no. 20, pp. 1615-1622, 1998.

[132] P. M. Ridker, C. P. Cannon, D. Morrow et al., "C-reactive protein levels and outcomes after statin therapy," The New England Journal of Medicine, vol. 352, no. 1, pp. 20-28, 2005.

[133] D. A. Morrow, J. A. de Lemos, M. S. Sabatine et al., "Clinical relevance of C-reactive protein during follow-up of patients with acute coronary syndromes in the Aggrastat-to-Zocor Trial," Circulation, vol. 114, no. 4, pp. 281-288, 2006.

[134] S. E. Nissen, E. M. Tuzcu, P. Schoenhagen et al., "Statin therapy, LDL cholesterol, C-reactive protein, and coronary artery disease," The New England Journal of Medicine, vol. 352, no. 1, pp. 29-38, 2005.

[135] P. M. Ridker, E. Danielson, F. A. Fonseca et al., "Reduction in Creactive protein and LDL cholesterol and cardiovascular event rates after initiation of rosuvastatin: a prospective study of the 
JUPITER trial," The Lancet, vol. 373, no. 9670, pp. 1175-1182, 2009.

[136] J. K. Liao, "Role of statin pleiotropism in acute coronary syndromes and stroke," International Journal of Clinical Practice, Supplement, no. 134, pp. 51-57, 2003.

[137] R. S. Rosenson and C. C. Tangney, "Antiatherothrombotic properties of statins: implications for cardiovascular event reduction," Journal of the American Medical Association, vol. 279, no. 20, pp. 1643-1650, 1998.

[138] J. J. Li and X. J. Chen, "Simvastatin inhibits interleukin-6 release in human monocytes stimulated by C-reactive protein and lipopolysaccharide," Coronary Artery Disease, vol. 14, no. 4, pp. 329-334, 2003.

[139] J. Musial, A. Undas, P. Gajewski, M. Jankowski, W. Sydor, and A. Szczeklik, "Anti-inflammatory effects of simvastatin in subjects with hypercholesterolemia," International Journal of Cardiology, vol. 77, no. 2-3, pp. 247-253, 2001.

[140] T. Wæhre, J. K. Damås, L. Gullestad et al., "Hydroxymethylglutaryl coenzyme A reductase inhibitors down-regulate chemokines and chemokine receptors in patients with coronary artery disease," Journal of the American College of Cardiology, vol. 41, no. 9, pp. 1460-1467, 2003.

[141] T. Wæhre, A. Yndestad, C. Smith et al., "Increased expression of interleukin-1 in coronary artery disease with downregulatory effects of HMG-CoA reductase inhibitors," Circulation, vol. 109, no. 16, pp. 1966-1972, 2004.

[142] A. D. Pradhan, J. E. Manson, N. Rifai, J. E. Buring, and P. M. Ridker, "C-reactive protein, interleukin 6, and risk of developing type 2 diabetes mellitus," Journal of the American Medical Association, vol. 286, no. 3, pp. 327-334, 2001.

[143] A. Festa, R. D’Agostino Jr., R. P. Tracy, and S. M. Haffner, "Elevated levels of acute-phase proteins and plasminogen activator inhibitor-1 predict the development of type 2 diabetes: the insulin resistance atherosclerosis study," Diabetes, vol. 51, no. 4, pp. 1131-1137, 2002.

[144] S. Nakanishi, K. Yamane, N. Kamei, M. Okubo, and N. Kohno, "Elevated C-reactive protein is a risk factor for the development of type 2 diabetes in Japanese Americans," Diabetes Care, vol. 26, no. 10, pp. 2754-2757, 2003.

[145] K. C. B. Tan, N. M. S. Wat, S. C. F. Tam, E. D. Janus, T. H. Lam, and K. S. L. Lam, "C-reactive protein predicts the deterioration of glycemia in Chinese subjects with impaired glucose tolerance," Diabetes Care, vol. 26, no. 8, pp. 2323-2328, 2003.

[146] B. Thorand, H. Löwel, A. Schneider et al., "C-reactive protein as a predictor for incident diabetes mellitus among middle-aged men: results from the MONICA Augsburg Cohort Study, 19841998," Archives of Internal Medicine, vol. 163, no. 1, pp. 93-99, 2003.

[147] J. I. Barzilay, L. Abraham, S. R. Heckbert et al., "The relation of markers of inflammation to the development of glucose disorders in the elderly: the Cardiovascular Health Study," Diabetes, vol. 50, no. 10, pp. 2384-2389, 2001.

[148] D. J. Freeman, J. Norrie, M. J. Caslake et al., "C-reactive protein is an independent predictor of risk for the development of diabetes in the west of Scotland coronary prevention study," Diabetes, vol. 51, no. 5, pp. 1596-1600, 2002.

[149] M. B. Snijder, J. M. Dekker, M. Visser et al., "C-reactive protein and diabetes mellitus type 2," Diabetologia, vol. 44, Supplement 1, article 115A, 2001.
[150] J. J. Senn, P. J. Klover, I. A. Nowak et al., "Suppressor of cytokine signaling-3 (SOCS-3), a potential mediator of interleukin-6dependent insulin resistance in hepatocytes," The Journal of Biological Chemistry, vol. 278, no. 16, pp. 13740-13746, 2003.

[151] J. C. Pickup and M. A. Crook, "Is type II diabetes mellitus a disease of the innate immune system?" Diabetologia, vol. 41, no. 10, pp. 1241-1248, 1998.

[152] W. K. Lagrand, C. A. Visser, W. T. Hermens et al., "Creactive protein as a cardiovascular risk factor more than an epiphenomenon?" Circulation, vol. 100, no. 1, pp. 96-102, 1999.

[153] P. A. Sakkinen, P. Wahl, M. Cushman, M. R. Lewis, and R. P. Tracy, "Clustering of procoagulation, inflammation, and fibrinolysis variables with metabolic factors in insulin resistance syndrome," American Journal of Epidemiology, vol. 152, no. 10, pp. 897-907, 2000.

[154] A. E. Hak, H. A. P. Pols, C. D. A. Stehouwer et al., "Markers of inflammation and cellular adhesion molecules in relation to insulin resistance in nondiabetic elderly: the Rotterdam Study," Journal of Clinical Endocrinology and Metabolism, vol. 86, no. 9, pp. 4398-4405, 2001.

[155] T. Temelkova-Kurktschiev, G. Siegert, S. Bergmann et al., "Subclinical inflammation is strongly related to insulin resistance but not to impaired insulin secretion in a high risk population for diabetes," Metabolism, vol. 51, no. 6, pp. 743-749, 2002.

[156] S. Müller, S. Martin, W. Koenig et al., "Impaired glucose tolerance is associated with increased serum concentrations of interleukin 6 and co-regulated acute-phase proteins but not TNF-alpha or its receptors," Diabetologia, vol. 45, no. 6, pp. 805812, 2002.

[157] T. Temelkova-Kurktschiev, "Subclinical inflammation in newly detected type II diabetes and impaired glucose tolerance," Diabetologia, vol. 45, no. 1, article 151, 2002.

[158] G. S. Hotamisligil, P. Arner, J. F. Caro, R. L. Atkinson, and B. M. Spiegelman, "Increased adipose tissue expression of tumor necrosis factor- $\alpha$ in human obesity and insulin resistance," The Journal of Clinical Investigation, vol. 95, no. 5, pp. 2409-2415, 1995.

[159] M. Saghizadeh, J. M. Ong, W. T. Garvey, R. R. Henry, and P. A. Kern, "The expression of TNF $\alpha$ by human muscle: relationship to insulin resistance," The Journal of Clinical Investigation, vol. 97, no. 4, pp. 1111-1116, 1996.

[160] P. Peraldi and B. Spiegelman, "TNF- $\alpha$ and insulin resistance: summary and future prospects," Molecular and Cellular Biochemistry, vol. 182, no. 1-2, pp. 169-175, 1998.

[161] A. Katsuki, Y. Sumida, S. Murashima et al., "Serum levels of tumor necrosis factor- $\alpha$ are increased in obese patients with noninsulin-dependent diabetes mellitus," Journal of Clinical Endocrinology and Metabolism, vol. 83, no. 3, pp. 859-862, 1998.

[162] G. Winkler, F. Salamon, D. Salamon, G. Speer, K. Simon, and K. Cseh, "Elevated serum tumour necrosis factor. alpha levels can contribute to the insulin resistance in Type II (non-insulindependent) diabetes and in obesity," Diabetologia, vol. 41, no. 7, pp. 860-862, 1998.

[163] J. C. Pickup, G. D. Chusney, S. M. Thomas, and D. Burt, "Plasma interleukin-6, tumour necrosis factor $\alpha$ and blood cytokine production in type 2 diabetes," Life Sciences, vol. 67, no. 3, pp. 291-300, 2000.

[164] B. Vozarova, C. Weyer, R. S. Lindsay, R. E. Pratley, C. Bogardus, and P. A. Tataranni, "High white blood cell count is associated with a worsening of insulin sensitivity and predicts the development of type 2 diabetes," Diabetes, vol. 51, no. 2, pp. 455-461, 2002. 
[165] D. M. Steel and A. S. Whitehead, "The major acute phase reactants: C-reactive protein, serum amyloid $\mathrm{P}$ component and serum amyloid A protein," Immunology Today, vol. 15, no. 2, pp. 81-87, 1994.

[166] G. R. Steinberg, "Inflammation in obesity is the common link between defects in fatty acid metabolism and insulin resistance," Cell Cycle, vol. 6, no. 8, pp. 888-894, 2007.

[167] F. Kim, K. A. Tysseling, J. Rice et al., "Free fatty acid impairment of nitric oxide production in endothelial cells is mediated by IKK $\beta$," Arteriosclerosis, Thrombosis, and Vascular Biology, vol. 25, no. 5, pp. 989-994, 2005.

[168] M. Roden, T. B. Price, G. Perseghin et al., "Mechanism of free fatty acid-induced insulin resistance in humans," The Journal of Clinical Investigation, vol. 97, no. 12, pp. 2859-2865, 1996.

[169] S. E. Shoelson, J. Lee, and M. Yuan, "Inflammation and the IKK beta/I kappa B/NF-kappa B axis in obesity- and diet-induced insulin resistance," International Journal of Obesity and Related Metabolic Disorders, vol. 27, Supplement 3, pp. S49-S52, 2003.

[170] G. S. Hotamisligil, "Inflammatory pathways and insulin action," International Journal of Obesity, vol. 27, no. 3, pp. S53-S55, 2003.

[171] D. Cai, M. Yuan, D. F. Frantz et al., "Local and systemic insulin resistance resulting from hepatic activation of IKK- $\beta$ and NF$\kappa$ B," Nature Medicine, vol. 11, no. 2, pp. 183-190, 2005.

[172] S. E. Shoelson, J. Lee, and A. B. Goldfine, "Inflammation and insulin resistance," The Journal of Clinical Investigation, vol. 116, no. 7, pp. 1793-1801, 2006.

[173] G. Bruno, P. Fornengo, G. Novelli et al., "C-reactive protein and 5 -year survival in type 2 diabetes: the casale monferrato study," Diabetes, vol. 58, no. 4, pp. 926-933, 2009.

[174] K. E. Wellen and G. S. Hotamisligil, "Inflammation, stress, and diabetes," The Journal of Clinical Investigation, vol. 115, no. 5, pp. 1111-1119, 2005.

[175] H. Kaneto, Y. Nakatani, T. Miyatsuka et al., "Possible novel therapy for diabetes with cell-permeable JNK-inhibitory peptide," Nature Medicine, vol. 10, no. 10, pp. 1128-1132, 2004.

[176] G. Liu and C. M. Rondinone, "JNK: bridging the insulin signaling and inflammatory pathway," Current Opinion in Investigational Drugs, vol. 6, no. 10, pp. 979-987, 2005.

[177] K. Maeda, H. Cao, K. Kono et al., "Adipocyte/macrophage fatty acid binding proteins control integrated metabolic responses in obesity and diabetes," Cell Metabolism, vol. 1, no. 2, pp. 107-119, 2005.

[178] R. S. Hundal, K. F. Petersen, A. B. Mayerson et al., "Mechanism by which high-dose aspirin improves glucose metabolism in type 2 diabetes," The Journal of Clinical Investigation, vol. 109, no. 10, pp. 1321-1326, 2002.

[179] A. B. Goldfine, R. Silver, W. Aldhahi et al., "Use of salsalate to target inflammation in the treatment of insulin resistance and type 2 diabetes," Clinical and Translational Science, vol. 1, no. 1, pp. 36-43, 2008.

[180] A. B. Goldfine, V. Fonseca, K. A. Jablonski, L. Pyle, M. A. Staten, and S. E. Shoelson, "The effects of salsalate on glycemic control in patients with type 2 diabetes: a randomized trial," Annals of Internal Medicine, vol. 152, no. 6, pp. 346-357, 2010.

[181] A. Fleischman, S. E. Shoelson, R. Bernier, and A. B. Goldfine, "Salsalate improves glycemia and inflammatory parameters in obese young adults," Diabetes Care, vol. 31, no. 2, pp. 289-294, 2008.

[182] J. Koska, E. Ortega, J. C. Bunt et al., "The effect of salsalate on insulin action and glucose tolerance in obese nondiabetic patients: results of a randomised double-blind placebocontrolled study," Diabetologia, vol. 52, no. 3, pp. 385-393, 2009.
[183] T. Sathyapalan, J. Shepherd, S. L. Atkin, and E. S. Kilpatrick, "The effect of atorvastatin and simvastatin on vitamin D, oxidative stress and inflammatory marker concentrations in patients with type 2 diabetes: a crossover study," Diabetes, Obesity and Metabolism, 2013.

[184] D. M. Cummings, D. E. King, and A. G. Mainous III, "C-reactive protein, antiinflammatory drugs, and quality of life in diabetes," Annals of Pharmacotherapy, vol. 37, no. 11, pp. 1593-1597, 2003.

[185] S. W. Rabkin, A. Langer, E. Ur, C. D. Calciu, and L. A. Leiter, "Inflammatory biomarkers CRP, MCP-1, serum amyloid alpha and interleukin-18 in patients with HTN and dyslipidemia: impact of diabetes mellitus on metabolic syndrome and the effect of statin therapy," Hypertension Research, 2013.

[186] A. M. Wägner, J. L. Sánchez-Quesada, S. Benítez, C. Bancells, J. Ordóñez-Llanos, and A. Pérez, "Effect of statin and fibrate treatment on inflammation in type 2 diabetes. A randomized, cross-over study," Diabetes Research and Clinical Practice, vol. 93, no. 1, pp. e25-e28, 2011.

[187] J. D. Colbert and J. A. Stone, "Statin use and the risk of incident diabetes mellitus: a review of the literature," Canadian Journal of Cardiology, vol. 28, no. 5, pp. 581-589, 2012. 


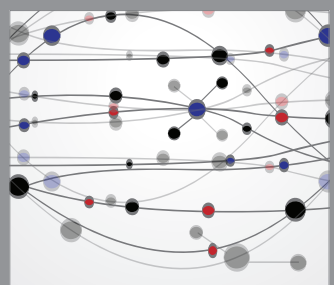

The Scientific World Journal
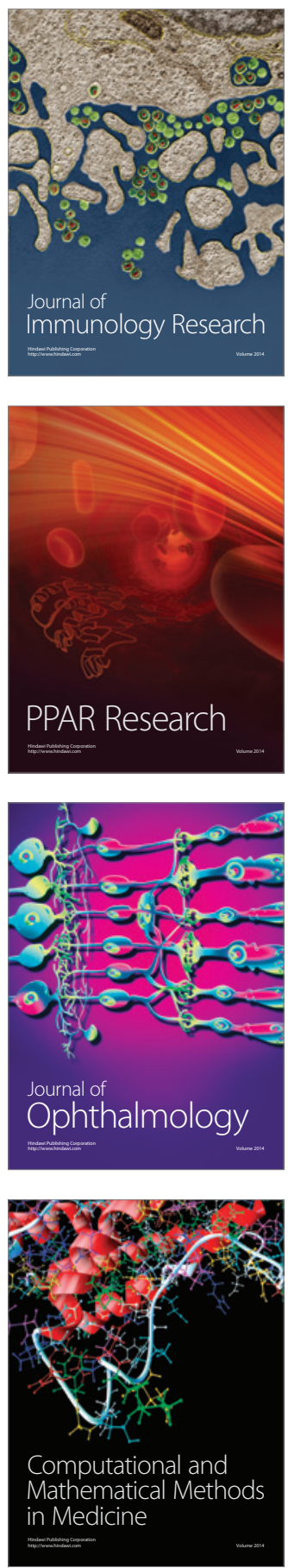

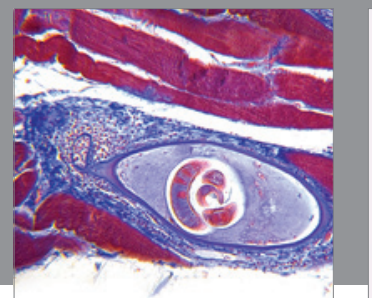

Gastroenterology

Research and Practice
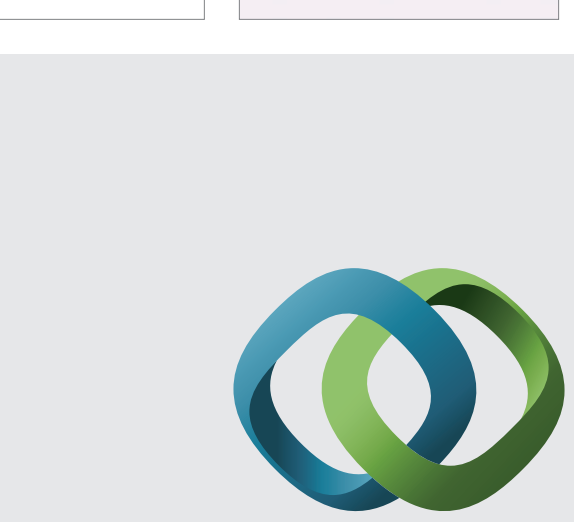

\section{Hindawi}

Submit your manuscripts at

http://www.hindawi.com
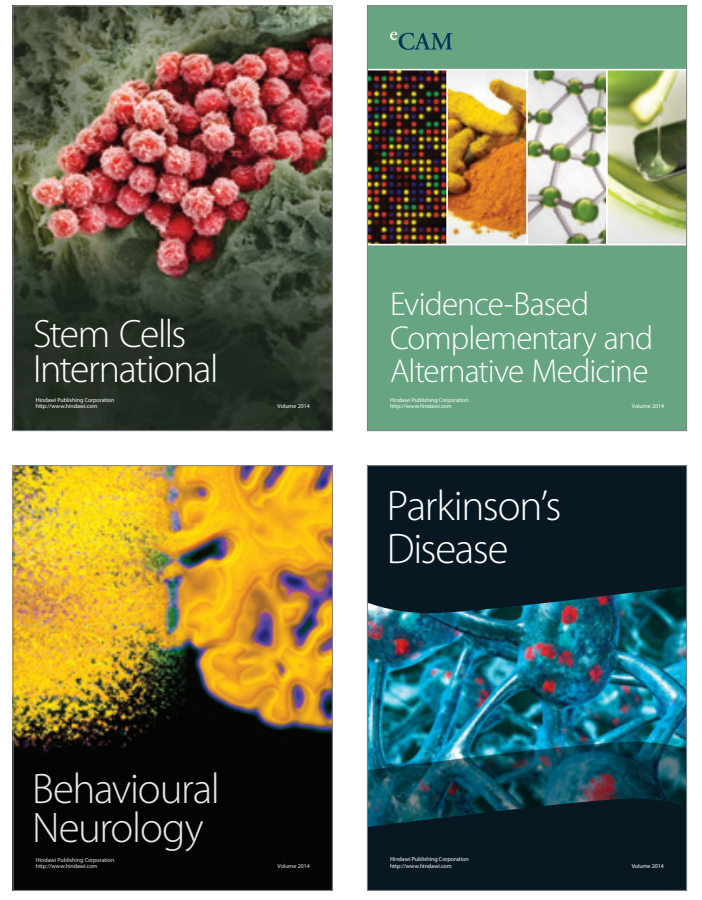
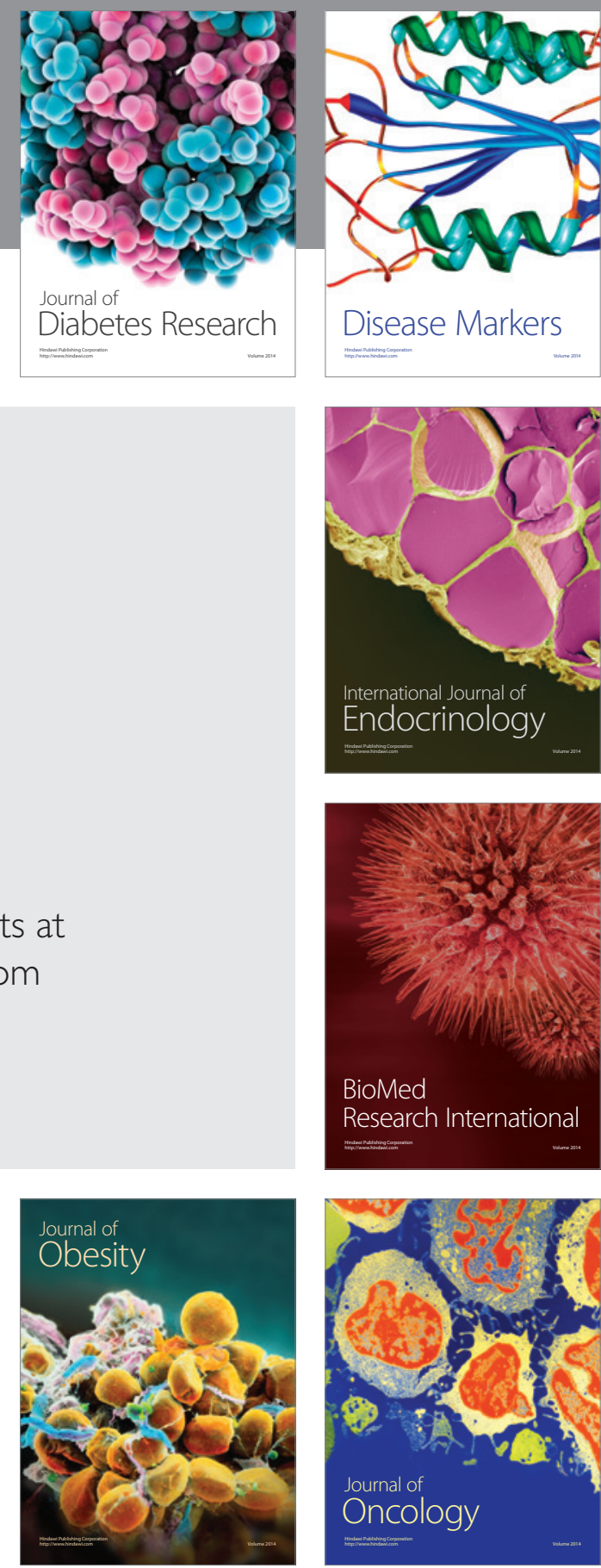

Disease Markers
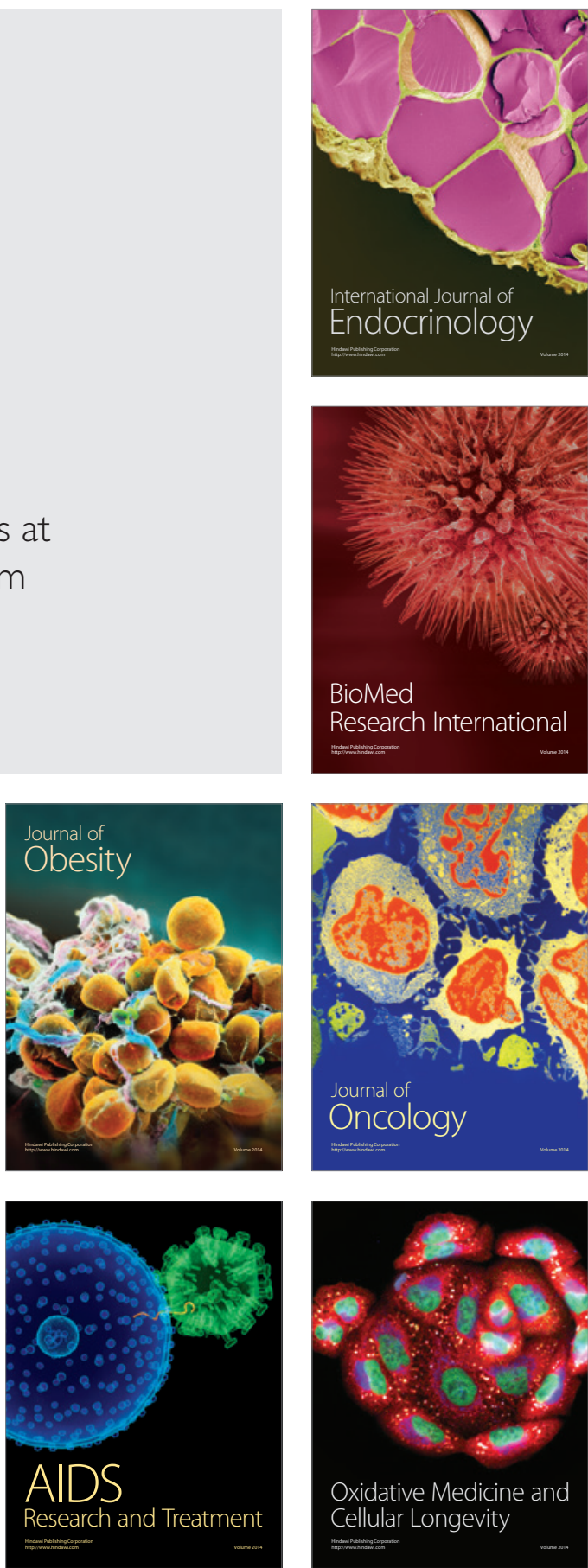